\section{perifèria}

Número 17, diciembre 2012

revistes.uab.cat/periferia

\title{
Building roads: an approach to the concepts of power, technology and conflicts in two Andean
}

\section{Countries}

Francisco Adolfo García Jerez

Estudiante del master en Estudios Latinoamericanos de la Universidad de Aberdeen y miembro del grupo de investigación GISAP ${ }^{1}$.

\begin{abstract}
Paths, bridges and roads are not only mechanisms to connect two or more geographical points. The existence of this type of communicating networks goes beyond their purely communicative function becoming, in the words of Bryan Pfaffenberger, a "technology of power" and therefore, in a capital subjected to power struggles among groups. Starting from this premise, the aim of this essay is to describe and analyse the multi-dimensional consequences the building of roads and paths have for society. For this reason, I have worked systematically on the definition of the idea of a road and its social meanings as well as established a theoretical frame based on the concepts of "power" by Steven Lukes, "agency" by John Law and "territorializing regime" by Fiona Wilson. Likewise, the article links this analytical proposal to several case studies located in Bolivia and Peru².
\end{abstract}

Key words: Technology of Power, Agency, Social Conflicts, Road, and Andean Countries.

\section{Resumen}

Los caminos, puentes y carreteras no sólo son mecanismos de conectividad entre dos o más puntos geográficos. La existencia de este tipo de redes de comunicación transciende su primara función comunicativa para convertirse, en palabras de Bryan Pfaffenberger, en una "tecnología de poder" y, por tanto, en un capital sujeto a disputa entre grupos. Partiendo de esta premisa, el presente artículo tiene como objetivo describir y analizar las múltiples dimensiones que supone la construcción de caminos y carreteras para las sociedades. Para ello, se ha abordado de forma sistemática la definición de lo que es y significa la idea de "carretera", se ha establecido un marco teórico basado en el concepto de "poder" de Steven Lukes,

\footnotetext{
${ }^{1}$ Enviar correspondencia a: Francisco Adolfo García Jerez, agarjer@upo.es.

${ }^{2}$ I would like to thank to Athenais A. Porret for her help in the correction of this text.
} 


\section{perifèria}

Número 17, diciembre 2012

revistes.uab.cat/periferia

de "agencia" de John Law y en la noción de "territorializing regime" de Fiona Wilson y se ha aplicado dicha propuesta analítica a varios casos de estudios localizados en Bolivia y Perú. Todo ello a partir fundamentalmente de fuentes secundarias.

Palabras claves: Tecnologías de Poder, Agencia, conflictos sociales, Carretera y Países Andinos.

John Ochsendorf (2005) shows us in a revealing video entitled "Engineering in the Andes Mountains: History and Design of Inca Suspension Bridges" the connection between the power of the State and roads. According to him, for the survival of the Inca Empire it was essential to build a wide variety of bridges in order to connect the extensive network of roads that crossed most of the Andes. This network was a key to the power of the Inca Empire, since it enabled military control of its territory as well as trade and exchanges. Another documentary, "Más allá de los Andes" (Mesa y Espinoza, 2009), also illustrates how according to the "Bohan Plan" the road between Cochabamba and Santa Cruz de la Sierra and the railway between Santa Cruz, Cambá and the Brazilien city of Chamine were built to promote trade among different Bolivian departments, as well as commercial activities between Bolivia, Brazil and Argentina. These infrastructures have been decisive factors in the economic development of the Bolivian nation-state, above all for the Eastern regions.

Based on these examples, the hypothesis could be drawn that a road is a technology, that it to say, a mechanism created by powerful social groups. For roads not only play a functional role communicating a place with another, but also are spatial relations that generate power relations as some groups get to have more influence on the behaviour of others (Wilson 2004; Harvey 2001). Thus, the road is a highly relevant key for understanding the building and development of society, since, according to Marx, the "technology reveals the active relation of man to nature, the direct process of the production of his life, and thereby it also lays bare the process of the production of the social relations of his life, and of the mental conceptions that flow from those relations" (Harvey 2010: 192). In order to analyse the importance of the road on Andean cultures, an analysis that reaches beyond its primary function as a communication device, this essay has 


\section{perifèria}

Número 17, diciembre 2012

revistes.uab.cat/periferia

been divided into three sections. The first will talk about the diverse ways of approaching the study of maps and roads attempting to clarify the underlying meanings and values of maps as representations of reality as well as their connection with roads. The second will deal with the concepts of power and technology and how they can be linked to the production of maps and roads. And the last will focus on examples of the uses and consequences of the building of roads in Andes societies in the past and in the present, analysing it as a technology of power that can generate strong social conflicts.

Likewise, I have to point out that this essay has been elaborated from secondary sources, especially academic literature on theoretical approaches to the study of roads and on specific cases located primarily in Bolivia and Peru. In addition, I have also examined documentaries and newspapers related to this problematic, and websites of Bolivian organizations involved in current conflicts produced by the attempt of road building.

\section{A first approach to the categories of maps and roads}

Until a few years ago, the study of maps was limited to cartographic analysis; to situate places, draw borders, or point out natural resources. However, postcolonial studies have focused their interest on the study and critical reading of maps, since they illustrate the views that the Spanish had of the lands and its indigenous people conquered by them, and how both were represented but also how the indigenous people have finally assumed these images and representations of themselves, their land and its effects.

One of the best-known authors is Harley, who tried to provide a new perspective on the nature of maps, in this case from a constructivist approach. Harley retakes the ideas of art historian Erwin Panofsky (1960), that is to say, to think of maps as if they were a language, a text about reality with which one can clarify its grammar, since inside this grammar is supposed to be found a kind of cultural code of the society that has generated the maps. In fact, Panofsky divided the study of maps in two categories: "iconography" and "iconology". Therefore, according to Harley (2001), it would be necessary to pay strong attention to the size of a map, the place where it establishes the centre-point, the colours, the texts, the names as

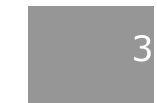




\section{perifèria}

Número 17, diciembre 2012

revistes.uab.cat/periferia

well as the blank spaces. From this analysis the researchers would be capable to detect the hegemonic logics of spatial and social representations existing in the maps' configuration.

Thus, following this proposal, authors such as Walter Mignollo (1995), Sousa Santos (2003) and Beatriz Piccolotto (2004) have carried out studies and research on the meanings of maps, especially during the American colonial period. One of the main conclusions for them is that maps are capable of creating and generating a worldview, which is frequently part of a systematic process of submission of other interpretative logics (Montoya 2007).

However, it is not only the Latin American academic world that has embraced this way of understanding the map. Authors from other countries have also contributed to develop this type of analysis. One of most sophisticated, interesting and comprehensive proposal was done by Orlove (1991, 1993), who analysed maps under two fundamental concepts. One of them was based on the idea of hegemony and his interest to clarify the relationship between social classes, while the second one was the definition of a system of domination based on Michel Foucault's assertion that domination includes the state apparatus as well as academic knowledge (2001).

Using both concepts and taking as starting point the proposal of Erwin Panofsky above mentioned, Orlove proposed two ways of examining maps: one of them he himself called "analysis of form", the other was named "analysis of practices". The first consists of the analysis of representational aspects along three main dimensions: "inclusion and exclusion of features, classification of features, and relations between features" (Orlove 1991: 4). While, the "analysis of practices" refers to how maps are seen by viewers, and therefore how maps influence their behaviour, since cartographic representations guide people to particular spots. This last approach includes two components: "the ethnographic of viewing" (that means, in my opinion, to contextualise the consumption of maps under two axes: space and time) and the "grouping of maps into different classes" (Orlove 1993: 30), that it to say, to create categories such as sketch, projection and drawing, where each map is located. 


\section{perifèria}

Número 17, diciembre 2012

revistes.uab.cat/periferia

However, as it was previously mentioned, maps are composed of a huge variety of elements, including roads. It could be stated that the importance of roads is essential in order to understand how places are articulated within the representation of reality and its production. Roads are a technology of power. Thus, to study this type of device it is indispensable to mention the works of Fiona Wilson, particularly her article titled "Towards a political economy of roads: experiences from Peru". In this text she tries to explore and link the "...mobility and movement, routes and roads, within relations of power and political economy" (Wilson 2004: 526). With this goal, she points out some questions such as "who decides how/where connections are made and how/where movement is challenged? (...) what does the state of the roads say about political economy?" (ibidem, 526). To respond to these questions, Wilson uses the concept of "territorializing regime", which combines the ideas of Lefebvre's social space (1991), Pierre Bourdieu's political field (1991), Roseberry's hegemonic authority (1994) and Agnew and Corbridge's geo-political reo-ordering of spatial scale (1995). Thus, she states that a "territorializing regime"

...is a process without closure, where claims to political/social space are constantly being brought into play (and constantly questioned). This involves colonization, maintaining routes, and exerting control over people and resources located at a distance. Strategies of persuasion and seduction as well as force come into play when the powerful try to impose/demarcate boundaries, classify regions and populations, guide, deploy and fix people in space (ibidem, 530).

To reuse these words of Wilson, maps and more particularly roads have been an essential key to configure the borders of the states. In fact, according to recent neurophysiology (Turball, 2000) the human brain creates and stores memories as maps. This means that human beings, as well as many animals, have the capacity to order the external world configuring cartographic representations with their "map sense" (mentioned in Turball 2002). However, although space is produced by biological process, it is also an external aspect subject to being ordered, structured or organised according to a hierarchy of values. Indeed, depending on each culture 


\section{perifèria}

Número 17, diciembre 2012

revistes.uab.cat/periferia

or each period in time, this spatial configuration will be configured in very different ways. Hence, as Turball states, "maps are the product of such transparent process as 'compilation, generalization, formation into hierarchies, and standardisation of geographical data" (Turball 2000: 99). Tracking history we find that one of the most relevant map-making age was the sixteenth century, during the expansion of the Portuguese and Spanish empires. This process of mapping meant an improvement in navigation which allowed a better control of the conquered territories by the empires, not only the Spanish or Portuguese, but also the English under Henry VII (Turball 2000: 105). In fact, as Peter Barber asserts (mentioned in Turball, 2000), maps were also used "to clarify and dispute over rights, ownership and jurisdiction" among kingdoms.

Roads carry out the same functions and meanings as maps since they are often the cartographic representations taken a charge of drawing limits, borders and frontiers of countries or regions. A historical well-known example is the Spanish colonial economy in the Peruvian Andes, which was composed of three territorializing regimes. On the top was the Spanish administration, followed by the Hacienda (property-owning), and, on the lowest level, the indigenous settlements and parishes. According to Wilson (2004), it could be asserted that each level was associated with a type of movement, that is to say, a type of route-making, in which the network of official roads served to establish taxes and reinforce the main administrative centres, but, likewise, allowed the Andean people to survive under extreme climatic conditions, since the system of roads in the pre-Hispanic period, communicating different places, offered shelters where travellers could rest. Unfortunately, this system collapsed as consequence of the arrivals of the Spaniards (Murra, 1984).

\section{On power and technology: different theoretical approaches to the study of roads}

Usually it is quite easy to find papers, articles and reports that deal with the concept of power. However, it seems more difficult to trace a definition of this category that would be a useful instrument to analyze reality, especially with regard to power struggles. One of the most relevant sociologists, Max Weber, attempted to 


\section{perifèria}

Número 17, diciembre 2012

revistes.uab.cat/periferia

clarify the meaning of power. For him, power is a coactive way to influence the behaviour of others (Weber 1971). Nonetheless, the philosopher Michel Foucault (2001) criticised this definition because power, according to him, can also be carried out through a discretional or persuasive way. Indeed, he thought that this last aspect was the most effective way to influence the perceptions and practices of a specific social group or even the whole of society. In any case, and in my opinion, power should include both approaches: the coactive and discretional ${ }^{3}$.

Likewise, with the goal to distinguish the nature of each type of power, and following Law's proposal based on the theory of Lukes (1974), four kind of power can be defined: "power to" (the influence on others), "power over" (the ability, the capacity or facility of individuals to influence others), "the power of store" (the unequal distribution of power among individuals) and "power discretion" (the capacity of those who possess power to choose between different lines of action (Law 1991). Together with these categories of power, Law defines another relevant notion: agency. That is to say: "agents are both sets of relations, and nodes in sets of relation" (Law 1991: 173). This concept is characterized by the following aspects: to be strategically organised, to have mixed strategies and, finally, the "agent is a structured set of relations with a series of (power) effects", (ibidem, 173).

Let us return to the concept of Technology, which is another key-word of this essay since the hypothesis defended here is that roads are clearly a technology, indeed, a technology of power. The question therefore is, "what is technology? (...) how does culture influence technological innovation-and how does technological innovation influence culture?" (Pfaffenberger 1992: 442).

Pfaffenberger defines the concept of technology as "the system of material resources, tools, operational sequences and skills, verbal and nonverbal knowledge, and specific modes of work coordination that come into play in the fabrication of materials artefacts" (Pfaffenberger 1992: 497). Likewise, he points out other

\footnotetext{
3 Lechtman (1994) also defends this definition of power. Indeed, she shows that one of the most relevant examples was the Inca Empire, since the technology of power, in this case, was not used exclusively in a coactive way, but had a strong ideological side too.
} 


\section{perifèria}

Número 17, diciembre 2012

revistes.uab.cat/periferia

notions linked to this such as "sociotechnical system", that is to say, the cultural context in which the technology is produced, including its link with the organization of labour, its function within the material production, but also its symbolic and social meaning. It would seem evident that technology plays an essential role for the material and symbolic survival as well as the adaptation and reproduction of social groups (Binford, mentioned in Pfaffenberger, 1992). Hence, according to Hughes, "those who seek to develop new technologies must concern themselves not only with techniques and artefacts; they must also engineer the social, economic, legal, scientific, and political context of the technology" (Pfaffenberger 1992: 498). Paradoxically, the possibility must be considered that a specific technology does not work, but, however, conserves its social meaning and symbolic function. In fact, as Pfaffenberger states, "the social anthropology of technology (...) should adopt a principle of absolute impartiality with respect to whether a given activity works (...) or 'doesn't work'..." (ibidem 1992: 501).

Thus, answering the second question above mentioned, it is evident that culture influences technology. A way to do this is through the relationship between ritual and the configuration and organization of labour. That is to say, through collective and periodic actions with a dense symbolic value (the ritual), thanks to ritual practice working conditions and labour relations (also technologies) receive a spiritual or intangible dimension. Thus, culture influences technology but, as has been mentioned above, technology, especially the new one, may modify culture too, since in order to be introduced it is necessary to change (at least partially) economic, political and legal aspects of the overall context.

Retaking the category of "agency" developed by Law (1991), some years ago historians and sociologists of technology suggested paying attention to the shapes adopted by devices, production arrangements, architectures and materials in general with which one can generate determined effects on some parts of society. Sometimes, as Law illustrates, that shape serves to reproduce the existing status quo or to reinforce the contexts of inequality and social segregation. One suitable example of this was the Long Island Parkway designed by Robert Moses. His engineering project was a railroad whose objective was to facilitate leisure activities for New Yorkers. However, this railroad did not allow for the circulation of buses in 


\section{perifèria}

Número 17, diciembre 2012

revistes.uab.cat/periferia

more peripheral neighbourhoods, which means that many black and working class sectors could not use it and therefore could not enjoy the newly available leisure space. Thus, as it can be observed, the shape of a device may cause evident and visible effects on the human behaviour from the exercise of power by those who possess it. In this case the device is not able to take initiative on its own, but it is an inert being used by humans. Nevertheless in some cultures such as those settled in the Peruvian and Bolivian Andes, the landscape is considered an agency in itself, that is to say, an actor with capacity to generate effects on the rest of the community. In academic terms, it could be defined as "lived environment" as a result of the beliefs that the mountains, rivers and the sky possess human characteristics and therefore human behaviour. As a consequence of their strength and abilities, depending on the eventual relationship with the community, the animated landscapes are able to cause negative or positive effects on individuals. Consequently, it should be considered as an evidence of the practice of power of agency. This is perfectly summarised by Harvey when she states the following:

These spirits are human-like and able to enter into productive mutually beneficial relationships in which each side sustains the needs of the other through exchanges of food, drink, music, talk- the stuff of human sociality. However, the spirits are also capricious and destructive, powerful and thus able to destroy if as well as sustain (Harvey 2001: 198-199).

Even roads could be included within this notion of "lived environment". On some occasions they are the embodiment of a strong symbolic meaning allowing them to act as an agency reinforcing social structure. One eloquent example of this was the "ceque system" (Zuidema, 1998, mentioned in Harvey 2001), which was the tracing of sacred lines that served to connect the centre of empire and the outlying regions. In fact, the Spanish conquerors continued with this system through the planting of crosses on the hill tops although with the goal of converting these lands from Inca belief places into Christian places (Harvey 2001).

Thus, apart from the close relationship between roads and maps, they differ since the first one has a real and indispensable function of communicating places with 


\section{perifèria}

Número 17, diciembre 2012

revistes.uab.cat/periferia

others as well as establishing material and symbolic boundaries. Roads have direct, physical power to interfere with the relationship between nature and society. Sometimes they are understood as an autonomous agency, as a "lived environment" with the power to influence the whole of society.

\section{A brief approach to some Bolivian and Peruvian cases}

Thus, three aspects will be indispensable in the analysis of roads within this framework. The first is the idea of a technology related to roads and road building since this may be understood in terms of materials, but also as knowledge and process-making. The second is the concept of power, because, as it has already been explained above, power means to have the capacity of affecting others, but, likewise, this refers to the category of agency, or to the social actor with that faculty. For the last point it is necessary to underline the notion of "lived environment". This means the perception of some ethnic groups that determined natural elements possess human characteristics and act like themselves. In fact, Fairheads (1992) studied the negative effects of road-building in Zaire. For him, roads are a proof of authority. Likewise he proposes to analyse roads from two perspectives: from the flow of goods and from the use by local people, since in the colonial time the natives were forced to build them as well as were obliged to pay taxes if they wished to use them. Another author that has studied the consequences of road-building was Poster (2002). In this case, his work focused on the effects of absence of paths between small-villages and the impossibility to access primary services or the incapacity of the local and rural people in SubSamarian Africa to make their claims and interests visible. Other examples are the surveys of Rigg (2002) and Nugent (1997). Both illustrate how sometimes a road may cause negative and even destructive effects for small villages such as Chachapoya (Peru), where the local inhabitants criticised the roads since, according to them, they had brought in outsiders responsible for increasing violence and extortion. Also, as Rigg states (2002), roads may mean that the local economy is submerged by mainstream interests, this being highly unfavourable for the community.

Undoubtedly, one the most interesting and illustrative research about the 


\section{perifèria}

Número 17, diciembre 2012

revistes.uab.cat/periferia

consequences of roads on local people in the Andean region is the work done by Fiona Wilson (2004). According to Wilson (2004) and the use of the concept of Regime, the Spanish colonial system was configured by "three superimposed territorializing regimes" led by the colonial administration, followed by the hacienda, that it to say, property-owning settlers, and finally by indigenous settlements and parishes. The most relevant issue with regard to this social hierarchy was the particular capacity of movement and, therefore, route-making of each regime. Thus, as mentioned above, the colonial administration used roads to charge taxes on goods, animals and people in transit. Likewise, this agent required from the indigenous people to build and maintain this web of roads. This conception, and the use of roads as an instrument of economic control on a specific area and population, is not restricted to the past. In fact, as Churats, Escalante and Laats (2001) show us, following globalization some current Peruvian Andean peasant communities have decided to carry out development programs in order to improve (and sometimes change) traditional ways of production and trade. For this it was indispensable to abandon the isolated condition most of them were in. With this goal, it was necessary to build a new network of roads through which these settlements could communicate with each other as well as with public and private institutions. This program was assumed by, among others, Santa Barbara de Huallhua and Nueva Esperanza communities, or more specifically the Cayash communities, which have been studied principally by Wilson. She concludes that road-building for theses indigenous Peruvian people possesses certain powerful meanings: first, through the road they can claim the property of their land and avoid its appropriation by other communities: second, to obtain the Peruvian citizenship and, therefore lose the label of terrorists; and third as a means against the image of being ignorant Indians as result of their isolation. However, other communities rejected this proposal, since for them the passing and improvement of the roads meant a remarkable increase of prices of their lands and, as a result, a clear rise of the taxes they should pay.

It seems interesting to stress the paradoxical conception that surrounds the hypothetical consequences of roads and its meanings. In the same context although for different social groups, a road became an instrument of domination and control, 


\section{perifèria}

Número 17, diciembre 2012

revistes.uab.cat/periferia

or is understood as a device to increase the quality of life for the community. One suitable example of the latter is Peru when it was liberated from the Spanish crown, since as Wilson asserts "the architects of the new Peruvian state hoped that a national system of roads, schools and civic celebration as well as activities such as map-making and census-taking would push the idea of state-ness out to the edge of civilization" (Wilson 2004: 532). However, as it was mentioned above, in many occasions the road, understood as technology and therefore fundamentally controlled by a few social groups, may become an instrument of power and sometimes of reproducing the status quo or the social hierarchy. Behind road building lies the racial idea that associates roads with mobility, with traders and brokers, and these with Mestizo, progress and civilization. While on the other hand, the enclosed community is identified with peasants, peasants with the Indian and this figure with backwardness. Hence, in the 1920s the number of kilometres of roads nearly doubled, from 10.643 to 19.456 , especially this policy of network roads reinforced the link between Lima and the coast (La carreterea Central). Likewise, together with this investment road-making trucks were introduced in Peru by the US firms General Motors and Ford Motor Company. This introduction, as Arguedas points out (1989), underlined "deeply racist patterns of privilege", since old landed elite felt offended by new truckers.

Moreover, it must be mentioned as well the re-configuration of product markets as consequence of the expansion of truck transport and the construction of that new network of roads. The new vehicles replaced animal transports therefore the llamas and mules lost their importance. Although this new context caused a notable increase in trade and exchanges between two remote places, in some occasions it also meant a high dependence on new technology, for instance, in the case of Colquemarca (Sotuhern Andes), where the replacement of animal transport by trucks prevented the trade in the wet season (Gade 1994).

In any case, it seems that the area where most social conflicts and more controversies are produced is in the linkage between roads and the protection of forests. It is certain that this problematic was based on the pretension of the State to construct networks that would cross forests in order to attract investment, a key idea of modernist development programs. However, indigenous people protest 


\section{perifèria}

Número 17, diciembre 2012

revistes.uab.cat/periferia

against that planning, since, according to their view, it could cause the destruction of their environment. Therefore not only natural resources for survival were in danger, but also sources of their gods and deep beliefs, since as Ingold suggests (2000), mountains, rivers and rocks are for rural indigenous people a "lived environment".

One of the most well-known examples of this was the attempt to create a road cutting through the Lorituyoc forest in the Paruro province of Peru. A forest in which, according to many researchers, there are approximately 300 varieties of trees and bushes. To stop the building of this road by the State, two communities (Rocoto and Huanca Huanca) decided to join forces and to organise an intercommunity committee. In this case the correlation of forces between both agencies is evident. On the one hand, the state, which possesses more power to control resources such as the economic (budget) and political capital (official authority), but also technology (and the capacity to justify it); and on the other the communities as counter-hegemonic groups, whose force lies in the social legitimacy they reach through the protest and public visualisation of the conflict and their interests.

However, the social relations of power and the interests are not always distributed within the "social field" (Bourdieu 1984) as clearly as in the last case. A current and excellent example of this is the designed and planned road crossing the "Territorio Indigena Parque Nacional Isiboro Sécure" (TIPNIS). This natural reserve was declared National Park in 22th November, 1965, being defined as indigenous territory on the $24^{\text {th }}$ September 1990. It is located between the Bolivian departments of Beni and Cochabamba. In this area (approximately $12.363 \mathrm{~km}^{2}$ ) live indigenous people such as the Yuki, Yurakare and Mojeno-trinitarios. The southern part of the park has been colonised by agricultural settlers related to the cultivation of coca since 1970s. This natural reserve is not situated in the Andes, however, its analysis allows us to understand and fix some concepts such as technology, power and its use, and the nature as "lived environment". Therefore, it can be easily being imagined to happen in the Andean region.

At the beginning of the conflict there was the idea of the indigenous president of Bolivia Evo Morales to build a road crossing the TIPNIS in order to communicate 


\section{perifèria}

Número 17, diciembre 2012

revistes.uab.cat/periferia

San Ignacio de Moxos with Villa Tunari. The goal was be to promote exchange and trade between both departments (Beni and Cochabamba), not only for agroalimentary goods, but also hydrocarbons (Lorenzo 2011). For this reason, even the Brazilian government was willing to finance part of this investment with 332 million of dollars (El Mundo, 25/11/2011). This initiative was supported by the Bolivian government, but also by the Camara Nacional de Comercio (El Diario, 26/10/2011). In contrast, the Confederation of Indigenous People of Bolivia (CIDOB) and the highland indigenous confederation (CONAMAQ) showed their opposition to this project. For them, this road means a threat for their modes of life, but also the destruction of their environment, understanding it not only as the source of materials and goods, but also as an essential part of their beliefs: the environment as Pachamama, and the Pachamama as "the mother nature". Hence, paradoxically, according to these organizations (Isiborosecure 2011), the Bolivian government consumed a clear contradiction because it had planned an initiative against a sacred aspect of the indigenous Bolivian culture, violating the New Constitution:

Por estos motivos demandamos al presidente Evo Morales, como defensor de la naturaleza y la madre tierra, y aplicando principios precautorios, ordene la suspensión inmediata de la construcción de la carretera Villa Tunari-San Ignacio de Moxos, por los riesgos e impactos que supone para los pueblos indígenas y su territorio, los ecosistemas y biodiversidad existente; al mismo tiempo, el gobierno debe realizar diseños alternativos fuera del TIPNIS (Isiboresecure, 2011) ${ }^{4}$.

However, not all indigenous groups shared this point of view. In fact, the coca producers and the indigenous of Chapare (gathered in the Coordinadora de Pueblos Indigenas del Tropico de Cochabamba and the Federacion de Campesinos de

\footnotetext{
4 Translation made by the author: "For these reasons, we claim to the president Evo Morales, as champion of Nature and Earth Mother, and applying caution principles, that he orders the rapid suspension of the road building Villa Tunari-San Iganio de Moxos, due to the risks and impacts that it means for the indigenous people and their territory, ecosystems and existing biodiversity; at the same time, the government must carry out alternative designs beyond TIPNIS". ("Campaña en Defensa del TIPNIS", 2010).
} 


\section{perifèria}

Número 17, diciembre 2012

revistes.uab.cat/periferia

Cochabamba) publicly showed their support for the road. For this reason, they organised a manifestation in the capital La Paz, during some days and nights reclaiming the building of the road, since they were convinced that this could improve education and the health system; of course TIPNIS did not affect their sacred environment (Los Tiempos 2011). Some main members of (CIDOB) and the highland indigenous confederation (CONAMAQ) accused Evo Morales of accepting the claims and pressures of coca producers because they are his most loyal political supporters (El Mundo 2011). In any case, apart from the brutal violence and repression practiced by the police forces to disperse the protesters, finally, on the $25^{\text {th }}$ October 2011, the Legislative Assembly passed a Law prohibiting the building of the road. Thus, according to president of Bolivia, Evo Morales, with this decision he and his government fulfilled a claim of the indigenous people from the East, who had carried out a hard march to La Paz from their regions of origin (El Mundo 2011).

It could be asserted that these last examples illustrate the quality of roads beyond their primary and more evident function of communicating places or spaces. Firstly, their importance lies in the meanings and values attached to them. While for a social group a specific road can mean social and economic development (more technically, progress for the community), others understand them as a real threat to the community, especially to the environment, which, for the Andean societies, is understood as a powerful being with human characteristics capable of influencing negatively or positively on the everyday life of a community. For this reason, roads often cause social conflicts, since each group attempts to control their planning and building. Therefore, roads have become a "political and economic capital" (according to Bourdieu 1984) and a "technology of power" (Pfaffenberger 1992), since they provoke profound changes in the social, economic, political and symbolic fields of a society. 


\section{perifèria}

Número 17, diciembre 2012

revistes.uab.cat/periferia

\section{References}

Agnew, J. and S. Corbridge (1995). Mastering Space: Hegemony, Territory and International Political Economy. London and New York: Routledge.

Bourdieu, Pierre (1984). Distinction: a Social Critique of the Judgment of Taste, Harvad University Press.

Bourdieu, Pierre (1991). Language and Symbolic Power. Cambrige: Polity Press.

El Diario (2011). "CNC: Bolivia necesita caminos", http://www.eldiario.net/noticias/2011/2011_10/nt111026/3_01ecn.php (accessed 03/11/2011).

El Mundo (2011). "Morales promulga una ley que prohíbe las carreteras en la reserva natural indígena" http://www.elmundo.es/america/2011/10/25/noticias/1319549882.html (accessed 25/11/2011).

Fairhead, J. (1992). "Paths of Authority: Roads, the State and the Market in eastern Zaire", European Journal of development Research 4(2): 17-35.

Foucault, Michel (2001). Un diálogo sobre el poder y otras conversaciones. Madrid: Alizanza.

Gades, D (1994). "Regional isolation in the high provinces of Cisco and Apurimac", in D. Poole (ed.) Unruly Order: Violence, Power and Cultural Identity in the High Provinces of Southern Peru, pp 31-62. Boulder, CO: Westview Press.

Harley, John (2001). The new nature of maps: essays in the history of cartography. Baltimore: The Johns Hopkins University Press, 2001.

Harvey, David (2010). "What Technology reveals", in A Companion to Marx's capital. London: Verso.

Harvey, Penelope (2001). "Landscape and Commerce: creating contexts for the exercise of power", in B. Bender (ed.) Contested Landscapes: Movement Exile and Place. Oxford, Berg.

Isiboresecure (2011). Campaña en Defensa del TIPNI. http://www.isiborosecure.com/tipnisdocucomunicado.htm, (accessed 27/10/2011). 


\section{perifèria}

Número 17, diciembre 2012

revistes.uab.cat/periferia

Ingold, Tim (2000). "To journey along a way of life: Maps, Wayfinding nad Navigation", in The Perception of the Environment: Essays on Livelihood, Dwelling and Skill, London: Routledge.

Law, John (1991). "Power, discretion and strategy", in J. Law (ed.) A sociology of Monster: Essays on Power, Technology and Domination. London: Routledge.

Lechtman, Heather (1994). "Technologies of Power: The Andean case", in Henderson and P. Netherley (eds.) Configurations of power: Holistic Anthropology in Theory and Practice. Ithaca: Cornell University Press.

Lefebvre, H. (1991). The production of space. Oxford: Blackwell.

Lorenzo, G. Ángel (2011). "Marcha indígena por el TIPNIS en Bolivia: ¿más que un simple problema?". Lima: Revista Andina de Estudios Políticos, Bolivia/número 9/Agosto-Septiembre 2011, pp. 1-17.

Los Tiempos (2011). "En Chapare se movilizan a favor de ruta por Tipnis" http://www.lostiempos.com/diario/actualidad/economia/20111028/

(accessed $03 / 11 / 2011)$

Lukes, Steven (1974). Power: a Radical View. London and Basingstoke: Macmillan. Mesa, Carlos y Espinoza, Mario (2009). Más allá de los Andes. Plano Medio. (Video). Mignolo, Walter (1995). The darker side of the renaissance. Literacy, territoriality, and colonization, Ann Harbor. The University of Michigan Press.

Montoya Arango, Vladimir (2007). "El mapa de lo invisible: silencios y gramática del poder en la cartografía", Bogotá, Universitas Humanística, 2007, enero-junio, no 063, 155-179.

Murra, John V. (1984). "Andean Society", Annual Rewiw of Anthropology, Vol 13 (1984), pp. 119-141.

Nugent, D (1997). Modernity at the edge of the Empire: State, Individual and Nation in the Northern Peruvian Andes, 1885-1935. Stanford, CA: Stanford University Press.

Ochsendorf, John (2005). Engineering in the Andes Montains: History and Design of 


\section{perifèria}

Número 17, diciembre 2012

revistes.uab.cat/periferia

Inca suspension Briges (Video).

Olorve, S. Benjamin (1991). "Mapping Reeds and Reading Mpas: the Politics of Representation in Lake Titicaca". American Ethnologist, Vol 18, N 1 (Feb., 1991), pp 3-38.

Olorve, S. Benjamin (1993). "The ethnography of Maps: the Cultural and Social Contexts of Cartographic Representation in Peru". Chicago: University of Chicago Press.

Panofsky, Erwin (1960). Renaissance and Renascences in Western Art. New York: Harper \& Row.

Pfaffenberger, Bryan (1992). "Social Anthropology of Technology". Annu. Rev. Antrhropol. 1992. 21: 491-516.

Piccolotto, Beatriz (2004). "Descifrando mapas: sobre o conceito de "território" e suas vinculacoes com a cartografía". Annais du Museu Paulista, 12 (12), 193-234.

Poster, G (2002). "Living in a Walking World: Rural Mobility and Social equity Isuues in Sub-Saharian Africa". World Development 30(2): 285-300.

Rigg (2002), J. (2002). "Roads, Marketisation and Social Exclusion: what do Roads do to Pepole?", Journal of the Humanities and Social Sciences of Southeast Asia and Oceania 158(4): 619-36.

Roseberry, W (1994). "Hegemony and the Language contention", in G. Joseph and D. Nugent (edts) Everyday Forms of state Formation: Revolution and the Negotiation of Rule in Modern Mexico, pp 335-66. Durham, NC: Duke University Press.

Sousa Santos, Boaventura (2003). Para un nuevo sentido común: la ciencia, el derecho y la política en la transición paradigmática. Volumen I. Bilbao: Editorial Desclée de Brouwer.

Turnbull, David (1994). "Towards a Political Economy of roads: Experiences from Peru", Development and Changes 35(3), pp 525-546.

Turnbull, David (2000). "Tricksters and cartographers: Maps, science and the state 


\section{perifèria}

Número 17, diciembre 2012

revistes.uab.cat/periferia

in the marking of a modern scientific knowledge space", in Masons, Tricksters and Cartographers, London: Routledge.

Weber, Max (1971). Economy and Society. Los Angeles: California University Press

Wilson, Fiona (2004). "Towards a political economy of roads: experiences from Peru", Development and Change 35(3), Institute of Social Studies: 525-546. 